\title{
Urine protein electrophoresis study in dogs with pituitary dependent hyperadrenocorticism during therapy with trilostane ${ }^{1}$
}

\author{
Douglas S. Caragelasco ${ }^{2 *}$, Márcia M. Kogika², Cínthia R. Martorelli², \\ Khadine K. Kanayama² and Denise M.N. Simões ${ }^{2}$
}

\begin{abstract}
Caragelasco D.S., Kogika M.M., Martorelli C.R., Kanayama K.K. \& Simões D. M.N. 2017. Urine protein electrophoresis study in dogs with pituitary dependent hyperadrenocorticism during therapy with trilostane. Pesquisa Veterinária Brasileira 37(7):734-740. Departamento de Clinica Médica, Faculdade de Medicina Veterinária e Zootecnia, Universidade de São Paulo, Av. Prof. Dr. Orlando Marques de Paiva 87, São Paulo, SP 05508-270, Brazil.E-mail: mv.douglas@usp.br

Hyperadrenocorticism is one of the most common endocrine disorders in dogs. Regarding to the kidneys, chronic hypercortisolemia can cause damage to the glomerulus, and evolve into chronic kidney disease. This study evaluated nine normotensive dogs with pituitary dependent hyperadrenocorticism, before and after therapy with trilostane, during the follow-up period of six months, in order to investigate the development of pathological proteinuria by quantitative (urinary protein-to-creatinine ratio) and qualitative (urinary protein electrophoresis) methods, and also to monitor its intensity over the course of the disease and therapy. The main renal lesion detected in dogs with hyperadrenocorticism was in the tubular segment, evidenced by the prevalence of urinary protein bands of lower molecular weight, indicating the lack absorption of these proteins in the proximal segment of the nephron. Low molecular weight proteins persisted throughout the follow-up. Regarding the future of routine veterinary medical clinic in the care of patients with hyperadrenocorticism, the assessments of proteinuria determinations by the urinary protein-to-creatinin ratio and urinary protein electrophoresis, according to the results obtained in this study, can add more information about the renal damage in these animals, and contribute to the prognosis.
\end{abstract}

INDEX TERMS: Hyperadrenocorticism, proteinuria, electrophoresis, trilostane, dog.

RESUMO.- [Avaliação da proteína urinária por eletroforese em cães com hiperadrenocorticismo hipófise dependente durante a terapia com trilostano.] Hiperadrenocorticismo (HAC) é uma das doenças endócrinas mais comuns em cães. A hipercortisolemia crônica pode causar danos glomerulares, pelo aumento da taxa de filtração glomerular, podendo levar ao desenvolvimento de doença renal crônica. Este estudo avaliou nove cães normotensos

\footnotetext{
${ }^{1}$ Received on August 17, 2016.

Accepted for publication on May 9, 2017.

${ }^{2}$ Departamento de Clínica Médica, Faculdade de Medicina Veterinária e Zootecnia (FMVZ), Universidade de São Paulo (USP), Av. Prof. Dr. Orlando Marques de Paiva 87, São Paulo, SP 05508-270, Brazil. E-mails: mv.douglas@usp.br, mmkogika@usp.br, cinthiarm@usp.br,khadinekk@usp.br,denisesimões.usp@gmail.com; *Corresponding author: mv.douglas@usp.br
}

com hiperadrenocorticismo hipófise-dependente, antes e após a terapia com trilostano, durante o período de acompanhamento de seis meses, a fim de investigar o desenvolvimento de proteinúria patológica por métodos quantitativo (relação proteína e creatinina urinária) e qualitativos (eletroforese de proteínas urinárias) e também para monitorar a sua intensidade ao longo do curso da doença e terapia. A principal lesão renal detectada em cães com HAC foi no segmento tubular, evidenciada pela prevalência de bandas de proteínas urinárias de peso molecular mais baixo, indicando a falta de absorção destas proteínas no segmento proximal do néfron. A proteinúria de baixo peso molecular persistiu durante todo o acompanhamento. Em relação ao futuro da rotina clínica médica veterinária no tratamento de cães com hiperadrenocorticismo, as avaliações de proteinúria pela relação proteína e creatinina urinária e eletro- 
forese de proteínas urinárias, de acordo com os resultados obtidos neste estudo, podem adicionar mais informações sobre a lesão renal nestes animais e contribuir para o prognóstico.

TERMOS DE INDEXAÇÃO: Hiperadrenocorticismo, proteinúria, eletroforese, trilostano, cão.

\section{INTRODUCTION}

Hyperadrenocorticism (HAC) or Cushing's syndrome is a well-recognized endocrine disorder in dogs characterized by the presence of excessive blood concentration of glucocorticoids secreted by the adrenal glands. Hypercortisolemia may be caused by the excessive secretion of adrenocorticotropic hormone (pituitary-dependent hyperadrenocorticism), or by the excessive secretion of cortisol due to a tumor in the adrenal gland (adrenal dependent), or also by the iatrogenic chronic administration of glucocorticoids (Peterson 2007).

Proteinuria is the hallmark of glomerular diseases and may be detected as one of the complications of HAC (Cook \& Cowgill 1996). In previous studies, $43.7 \%$ of HAC dogs with pituitary dependent hyperadrenocorticism had urinary protein-to-creatinine ratio (UPC) above 1.0 (Cavalcante et al. 2007), and UPC $<0.5$ in non azotemic dogs is considered normal (Hurley \& Vaden 1998). In another study, Cavalcante et al. (2013) noticed UPC $>1.0$ in $69.2 \%$ of HAC dogs with systemic hypertension and $47.1 \%$ in normotensive HAC dogs, and albuminuria was detected in $100 \%$ and $64.3 \%$, respectively. In untreated dogs with HAC, UPC was increased in $46 \%$, and in HAC dogs under treatment, but with poor control, 31\% had high UPC (Ortega et al. 1996). Those studies were conducted using different methodologies to assess proteinuria (e.g. by Coomassie brilliant blue or Pyrogallol red) as well as the HAC dogs were assessed only one time which does not allow an adequate interpretation of the results, according to the 2004 ACVIM forum consensus of proteinuria in small animals in veterinary medicine (Lees et al. 2005). The sequential evaluation of proteinuria could be the great value for monitoring the progression of the disease and completion suitable for analysis of data.

Glomerulonephritis associated with hyperadrenocorticism is still poorly understood. Waters et al. (1997) indicated that the immunosuppressive effects and glomerular hypertension may be associated with the cause of the renal proteinuria. It seems that chronic hypercortisolemia increases glomerular filtration rate (GFR) and, thereafter, increases glomerular membrane permeability, leading to glomerular injury (Smets et al. 2012b).

Thus currently, four mechanisms have been described to trigger renal proteinuria in dogs with chronic hypercortisolemia, and it includes: (1) changing in glomerular capillary permeability, (2) increase in tubular secretion of proteins, (3) decrease in tubular reabsorption of proteins and (4) the excess of volume filtration that allows the passage of large amounts of proteins through the glomerulus that overlaps the capacity of tubular reabsorption (Smets et al. 2010, 2012b, 2012c).
Lesions in different locations of the nephrons result in particular patterns of urinary proteins according to the molecular weights (Zaragoza et al. 2003). Macromolecular proteinuria, it means, loss of proteins of high molecular weight (HMWP), over $60 \mathrm{kDa}$, has been associated with glomerular damage (Schultze \& Jensen 1998), and micromolecular proteinuria, loss of proteins of low molecular weight (LMWP), under $60 \mathrm{kDa}$, has been correlated with tubular and/or interstitial damage (Schultze \& Jensen 1998).

Regarding to the treatment of dogs with pituitary dependent hyperadrenocorticism, trilostane Vetoryl $^{\mathbb{Q}}$; Dechra) has been recommended in an attempt to inhibit the synthesis of glucocorticoids, thus decreasing its circulating levels and minimizing organic changes (Vaughan \& Feldman 2008, Kooistra \& Galac 2010, Feldman 2011, Cho et al. 2013).

In dogs, few studies have investigated the relationship between HAC and renal injury (Waters et al. 1997, Hurley \& Vaden 1998, Cavalcante et al. 2007, Smets et al. 2012a, 2012c). Therefore, because of the lack of information regarding to the renal origin of proteinuria in HAC dogs, the aim of this study was to sequentially evaluate quantitatively and qualitatively, over the course of the disease and treatment, proteinuria and the molecular weights of urinary proteins, in order to add more information to detect renal lesions and the segments of nephrons involved that may have caused the loss of those proteins.

\section{MATERIALS AND METHODS}

The study was approved by the Committee on the Ethics of Animal Experimentation of the School of Veterinary Medicine and Animal Science, Universidade de São Paulo (Protocol \# 2254/2011), and conducted with nine normotensives dogs with HAC that were diagnosed based on clinical manifestations such as polyuria, polydipsia, panting, abdominal distension, alopecia, hepatomegaly, physical exam, and consistent results on combination of screening methodologies, low-dose dexamethasone suppression test and abdominal/adrenal ultrasound. Data were recorded before treatment (T0) one month after treatment (T1), three months after treatment (T2) and six months after treatment (T3). The dogs were treated with trilostane at dosage of $1.0 \mathrm{mg} / \mathrm{kg}$ BID, as described in previous publications (Alenza et al. 2006, Vaughan \& Feldman 2008, Feldman 2011).

Systolic arterial pressure was determined by an indirect method (Doppler Ultrasound Parks Medical ${ }^{\circledR}$ Model 811-B), and it was taken before any procedure, according to the guidelines of the ACVIM Consensus Statement on Systemic Hypertension. Systemic hypertension was defined as systolic pressure above $150 \mathrm{mmHg}$ (Brown et al. 2007). Biochemical profile was performed (analysed by Labmax 240 - Labtest ${ }^{\circledR}$ ). Serum cortisol was measured using radioimmunoassay method (Coat-A-Count Cortisol ${ }^{\circledR}$ ). Diagnosis of HAC (T0) was considered for serum cortisol values greater than $1.4 \mathrm{mg} / \mathrm{dL}$ after 8 hours of dexamethasone (Feldman 2011). For the ACTH stimulation test that was performed at T1, T2, T3, serum samples were collected for cortisol serum measurements before and one hour after intravenous administration of ACTH $(0.01 \mathrm{mg} / \mathrm{kg})$. The optimal levels of serum cortisol that was considered for the animals treated with trilostane ranged between $2 \mathrm{mg} / \mathrm{dL}$ and $5 \mathrm{mg} / \mathrm{dL}$ (Feldman 2011). 
Urinalysis and urine bacterial culture were performed on all dogs and no bacteriuria, hematuria or leukocyturia were detected in order to exclude post-renal proteinuria. The urine supernatant was stored at $-80^{\circ} \mathrm{C}$ for protein determination by Bradford method (Bradford 1976) (Coomassie brilliant blue G-250, Sigma ${ }^{\circledR}$ ), and for electrophoresis analysis by sodium dodecyl sulphate polyacrilamide gel electrophoresis (SDS-PAGE).

The SDS-PAGE is a high resolution technique using a sensitive silver stain for qualitative identification of protein bands according to molecular weights (Waters et al. 1997). As standard proteins, Precision Plus Protein Kaleidoscope 161-0375 (BioRad ${ }^{\circledR}$ ) was used. The image of the proteins bands was evaluated by densitometry system (Epson Expression ${ }^{\circledR}$ densitometer model 1680) and analyzed with a specific software program (Works Vision Ultra-Violet Products Ltd $^{\circledR}$ ). The SDS-PAGE patterns were classified according to the proteins inherent in it, and the percentage of protein concentration in each region (HMWP and LMWP) was also determined.

Sequential evaluation and statistical analysis were performed at four different time points (T0, T1, T2, T3). Data distribution was analyzed by the Kolmogorov-Smirnov test. Parametric tests were ANOVA followed by the Dunnett's post-hoc test to compare each time points (T0, T1, T2, T3) with the control group. Differences were considered significant at $P$ values less than 0.05 , and data were presented as mean \pm standard error of mean (SEM) unless otherwise noted.

\section{RESULTS}

Nine normotensive dogs with hyperadrenocorticism (age ranged from 56 to 151 months; $101 \pm 9.2$ months) and nine clinically normal dogs (age ranged from 36 to 108 months; $62.4 \pm 10.1$ months) were included in the study. Five out of 9 dogs with hyperadrenocorticism were female (55.5\%). Poodle ( 6 out of $9 ; 66.6 \%$ ) was the most frequent breed, followed by Pit Bull Terrier (1 out of 9; 11.1\%), Yorkshire Terrier ( 1 out of $9 ; 11.1 \%$ ), and Golden Retriever (1 out of 9; 11.1\%).

The most common clinical signs reported initially were polyphagia in $100 \%$, polyuria in $100 \%$, polydipsia in $90 \%$, abdominal distention in $100 \%$, endocrine alopecia $90 \%$ and panting in $60 \%$ of the cases. After six months of treatment (T3), the clinical signs of polyuria, polydipsia and polyphagia disappeared in all the dogs, the signs of endocrine alopecia and abdominal distention were ameliorated in $80 \%$ and $50 \%$ respectively, in the dogs that initially had these alterations, as shown in Figure 3.

All HAC dogs in the study were non-azotemic and the means and SEM of serum urea observed in the dogs along the follow-up period were $42.06 \pm 8.77 \mathrm{mg} / \mathrm{dL}, 48.24 \pm 9.86 \mathrm{mg} /$ $\mathrm{dL}, 43.04 \pm 10.06 \mathrm{mg} / \mathrm{dL}$ and $46.51 \pm 14.08 \mathrm{mg} / \mathrm{dL}$ respectively, at T0, T1, T2 and T3 (Table 1). The means and SEM of serum creatinine observed in the dogs along the follow-up period were $0.80 \pm 0.08 \mathrm{mg} / \mathrm{dL}, 0.85 \pm 0.08 \mathrm{mg} / \mathrm{dL}, 0.86$ $\pm 0.07 \mathrm{mg} / \mathrm{dL}$ and $0.91 \pm 0.10 \mathrm{mg} / \mathrm{dL}$, respectively, at $\mathrm{T} 0, \mathrm{~T} 1$, $\mathrm{T} 2$ and T3 (Table 1). No significant changes on serum urea or creatinine were detected after treatment with trilostane in these dogs (ANOVA, $\mathrm{P}=0.18$ and $\mathrm{P}=0.36$ respectively).

For follow-up of the patients were performed the serum measurement of serum protein, albumin, alkaline phosphatase, alanine aminotransferase, cholesterol, triglycerides and glycemia, as described in Table 2.
Table 1. Summary statistics for serum urea (UREA), serum creatinine (CREAT), urinary protein-to-creatinine ratio (UPC), percentage of high molecular weight protein (\% HMWP), percentage of low molecular weight protein (\% LMWP), numbers of protein bands of high molecular weight protein (NPB of HMWP) and numbers of protein bands of low molecular weight protein (NPB of LMWP) in clinically normal dogs (control; $n=10$ dogs) and in dogs with hyperadrenocorticism ( $n=9$ dogs), before (T0) and after (T1, T2 and T3) treatment with trilostane

\begin{tabular}{|c|c|c|c|c|c|c|c|}
\hline & & T0 & $\mathrm{T} 1$ & $\mathrm{~T} 2$ & T3 & Control & $\begin{array}{l}\text { ANOVA P } \\
\text { (T0 - T3) }\end{array}$ \\
\hline UREA & Mean & 42.06 & 48.24 & 43.04 & 46.51 & 39.29 & 0.18 \\
\hline \multirow[t]{4}{*}{$(\mathrm{mg} / \mathrm{dL})$} & Min & 21.50 & 20.00 & 17.00 & 19.90 & 19.00 & \\
\hline & Max & 59.8 & 65 & 57.2 & 62 & 60.10 & \\
\hline & SD & 26.31 & 29.59 & 30.19 & 39.84 & 12.94 & \\
\hline & SEM & 8.77 & 9.86 & 10.06 & 14.08 & 4.08 & \\
\hline \multirow{5}{*}{$\begin{array}{l}\text { CREAT } \\
\text { (mg/dL) }\end{array}$} & Mean & 0.80 & 0.85 & 0.86 & 0.91 & 1.12 & 0.36 \\
\hline & Min & 0.46 & 0.42 & 0.54 & 0.62 & 0.18 & \\
\hline & Max & 1.30 & 1.40 & 1.30 & 1.40 & 1.40 & \\
\hline & SD & 0.24 & 0.26 & 0.54 & 0.62 & 0.18 & \\
\hline & SEM & 0.08 & 0.08 & 0.07 & 0.10 & 0.05 & \\
\hline \multirow[t]{5}{*}{ UPC } & Mean & $1.18^{*}$ & $1.13^{*}$ & $0.99 *$ & $0.90^{*}$ & 0.12 & 0.36 \\
\hline & Min & 0.08 & 0.04 & 0.12 & 0.03 & 0.03 & \\
\hline & Max & 3.01 & 2.93 & 3.68 & 2.41 & 0.04 & \\
\hline & SD & 1.27 & 1.21 & 1.33 & 1.09 & 0.12 & \\
\hline & SEM & 0.42 & 0.40 & 0.44 & 0.38 & 0.04 & \\
\hline \multirow[t]{5}{*}{ \% HMWP } & Mean & $22.5^{* *}$ & $21.2^{* *}$ & $25.0 * *$ & $21.5^{* *}$ & 45.7 & \\
\hline & Min & 5.8 & 0 & 0 & 0 & 28.9 & \\
\hline & Max & 37.7 & 61.3 & 40.7 & 39.3 & 80.3 & \\
\hline & SD & 11.3 & 20.4 & 14.4 & 13.3 & 14.5 & \\
\hline & SEM & 3.8 & 6.8 & 4.8 & 4.7 & 4.6 & \\
\hline \multirow[t]{5}{*}{ \% LMWP } & Mean & $77.5^{* *}$ & $78.5^{* *}$ & $74.9^{* *}$ & $78.5^{* *}$ & 54.3 & 0.50 \\
\hline & Min & 62.3 & 38.7 & 59.3 & 60.7 & 19.7 & \\
\hline & Max & 94.2 & 100.0 & 100.0 & 100.0 & 71.1 & \\
\hline & SD & 11.3 & 20.4 & 14.4 & 13.3 & 4.6 & \\
\hline & SEM & 3.8 & 6.8 & 4.8 & 13.3 & 4.6 & \\
\hline NPB of & Mean & 2.4 & 1.4 & 1.8 & 1.9 & 2.3 & 0.94 \\
\hline \multirow[t]{4}{*}{ HMWP } & Min & 1 & 0 & 0 & 0 & 1 & \\
\hline & Max & 4 & 3 & 4 & 4 & 4 & \\
\hline & SD & 1.1 & 1.1 & 1.1 & 1.2 & 0.8 & \\
\hline & SEM & 3.8 & 6.8 & 4.8 & 13.3 & 4.6 & \\
\hline NPB of & Mean & $6.1^{*}$ & $5.2^{*}$ & $5.4^{*}$ & $5.7^{*}$ & 3.7 & 0.73 \\
\hline \multirow[t]{4}{*}{ LMWP } & Min & 3 & 2 & 4 & 4 & 1 & \\
\hline & Max & 8 & 7 & 8 & 7 & 8 & \\
\hline & SD & 1.6 & 2.0 & 1.4 & 1.0 & 1.9 & \\
\hline & SEM & 0.5 & 0.7 & 0.5 & 0.4 & 0.6 & \\
\hline
\end{tabular}

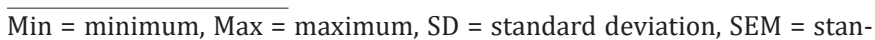
dard error of mean. * Significant difference $(\mathrm{P}<0.005)$ compared to the control group by Dunnet's post hoc, ${ }^{* *}$ significant difference $(\mathrm{P}<0.001)$ compared to the control group by Dunnet's post hoc.

Abdominal ultrasonography was performed in all dogs, and all dogs with HAC presented bilateral enlargement of the adrenal glands, and seven dogs with $\operatorname{HAC}(\# 1, \# 3$, \#4, $\# 5, \# 6, \# 8, \# 9$ ) revealed a marked increase in hepatic echogenicity and no abnormalities was found in the kidney of the HAC dogs.

The means and SEM of UPC observed in all HAC dogs along the follow-up period were $1.18 \pm 0.42,1.13 \pm 0.40$, $0.99 \pm 0.44$ and $0.90 \pm 0.38$ respectively, at $\mathrm{T} 0, \mathrm{~T} 1, \mathrm{~T} 2$ and T3 (Table 1). No significant changes on UPC were detected after treatment with trilostane in these dogs (ANOVA, $\mathrm{P}=0.36$ ). No alterations on UPC, along the follow-up when observed the dogs individually, were detected. Six dogs with HAC (\#1, \#2, \#3, \#5, \#6 and \#8) were non-proteinuric 
Table 2. Summary statistics for serum total protein (PROT) albumin (ALB), alkaline phosphatase (ALP), alanine aminotrasnsferase (ALT), cholesterol (CHOL), triglycerides (TRI) and glycaemia (GLY) in clinically normal dogs (control; $\mathrm{n}=10 \mathrm{dogs}$ ) and in dogs with hyperadrenocorticism ( $n=9$ dogs), before (T0) and after (T1, T2 and T3) treatment with trilostane

\begin{tabular}{llllll}
\hline T0 & T1 & T2 & T3 & Control & ANOVA \\
& & & & & P (T0 - T3) \\
\hline
\end{tabular}

\section{PROT}

$(\mathrm{mg} / \mathrm{dL})$

$\begin{array}{lcccccc}\text { (mg/dL) } & \text { Mean } & 6.65 & 6.14 & 6.52 & 6.38 & 6.30 \\ & \text { Min } & 6.00 & 5.50 & 6.00 & 5.70 & 5.70 \\ & \text { Max } & 7.40 & 7.40 & 7.00 & 6.90 & 6.80 \\ & \text { SD } & 0.48 & 0.50 & 0.38 & 0.37 & 0.33 \\ & \text { SEM } & 0.15 & 0.15 & 0.12 & 0.12 & 0.10 \\ \text { ALB } & \text { Mean } & 3.37 & 3.29 & 3.23 & 3.11 & 3.41 \\ (\mathrm{mg} / \mathrm{dL}) & \text { Min } & 2.90 & 2.60 & 2.70 & 2.60 & 3.10 \\ & \text { Max } & 4.10 & 3.70 & 4.10 & 3.60 & 3.90 \\ & \text { SD } & 0.33 & 0.34 & 0.45 & 0.40 & 0.21 \\ & \text { SEM } & 0.10 & 0.10 & 0.14 & 0.13 & 0.06 \\ \text { ALP } & \text { Mean } & 157.34^{*} & 227.72 * & 384.20 * & 371.04^{*} & 30.7 \\ & \text { Min } & 43.40 & 38.70 & 44.30 & 26.80 & 20.30 \\ & \text { Max } & 346.00 & 850.00 & 1567.07 & 1337.00 & 41.0 \\ & \text { SD } & 90.03 & 249.21 & 556.07 & 505.39 & 6.00\end{array}$

SEM

ALT

TRI

CHOL

Mean 91.62*

\section{$81.22 *$}

$87.35^{*}$

Min $\quad 9.60 \quad 13.20$

Max $219.70 \quad 175.30$

$22.38 \quad 20.10 \quad 15.20$

SD $\quad 62.82$

52.76

SEM $\quad 19.87 \quad 16.69$

186.90

70.78

\subsection{7}

297.31

Min 203.80

Max 631.90

171.10

149.9

$52.29 \quad 9.56$

$17.43 \quad 3.02$

SD 134.07

598.90

523.10

299.81225 .00

218.00155 .90

$\begin{array}{llllll}\text { SEM } & 42.39 & 44.63 & 36.88 & 28.39 & 16.60\end{array}$

Mean 246.95* 152.64* 194.98* 149.55* 56.00

$\begin{array}{llllll}\text { Min } & 57.00 & 71.00 & 57.10 & 29.80 & 39.60\end{array}$

$\begin{array}{llllll}\text { Max } & 673.70 & 275.80 & 442.20 & 341.90 & 79.00\end{array}$

$\begin{array}{llllll}\text { SD } & 186.28 & 86.26 & 121.27 & 99.23 & 13.61\end{array}$

SEM $\quad 221.55 \quad 113.65 \quad 152.95 \quad 131.70 \quad 60.05$

GLY Mean $\quad 90.90^{*} \quad 83.40 \quad 82.10 \quad 81.00 \quad 71.90$

$\begin{array}{llllll}\text { Min } & 65.00 & 65.00 & 70.00 & 67.00 & 54.00\end{array}$

$\begin{array}{llllll}\text { Max } & 110.00 & 99.00 & 96.00 & 93.00 & 88.00\end{array}$

$\begin{array}{lllllll}\text { SD } & 14.00 & 10.83 & 8.95 & 7.76 & 11.26\end{array}$

$\begin{array}{llllll}\text { SEM } & 4.43 & 3.43 & 2.83 & 2.59 & 3.56\end{array}$

Min $=$ minimum, Max $=$ maximum, $\mathrm{SD}=$ standard deviation, $\mathrm{SEM}=$ standard error of mean. * Significant difference $(\mathrm{P}<0.005)$ compared to the control group by Dunnet's post hoc, ${ }^{* *}$ significant difference $(\mathrm{P}<0.001)$ compared to the control group by Dunnet's post hoc.
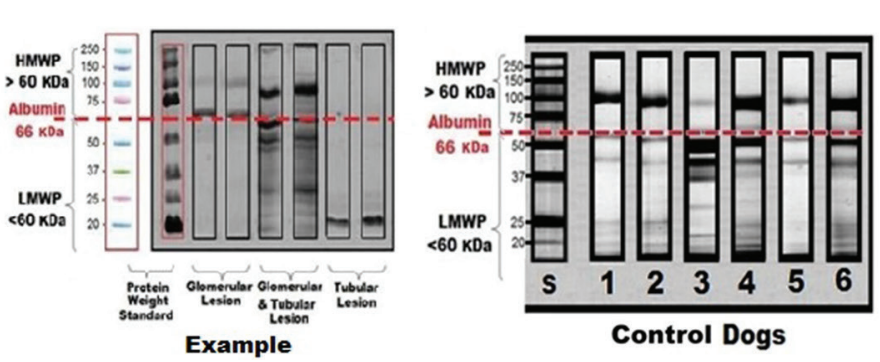

(UPC $<1.0$ ), and UPC greater than 2.0 was observed in three dogs (\#4, \#7 and \#9).

In regard to the ACTH stimulation test after initiation of treatment with trilostane, at T2 most of the HAC dogs had satisfactory response to ACTH stimulation test, and at T3 all the dogs had good control as serum cortisol levels were in the expected normal range values (Fig.1).

In the assessment of urine protein bands according to the molecular weight of control group, an average of five bands was found and those bands were distributed on average of $44.7 \%$ in the region of HMWP (approximately with 2 protein bands) and 54.3\% in the region of LMWPB (approximately with 3 protein bands) (Fig.2). The distribution of protein bands in dogs with HAC was different to that observed in the control group. In HAC dogs, the percentages of HMWP were $22.5 \pm 3.8 \%, 21.2 \pm 6.8 \%, 25.0 \pm 4.8 \%$ and $21.5 \pm 4.7 \%$ respectively, at $\mathrm{T} 0, \mathrm{~T} 1, \mathrm{~T} 2$ and $\mathrm{T} 3$, and in the region of LMWP were $77.5 \pm 3.8 \%, 78.5 \pm 6.8 \%, 74.9 \pm 4.8 \%$ and 78.5 $\pm 4.6 \%$ (Table 1).

The HAC dogs also showed different number of protein bands in the region of LMWP; the mean was approximately 6, 5, 5 and 6 bands, respectively, at T0, T1, T2 and T3 (Table 1). The HAC dogs \#1, \#2, \#3, \#4, \#5, \#8 and \#9 had mixed pattern of proteinuria (glomerular and tubular), while HAC dogs \#6 and \#7 showed glomerular pattern of proteinuria (Fig.3).

No significant alterations in the summary statistics (ANOVA) were detected along the follow-up period (T0 to T3) for all the variables such as percentage of HMWP

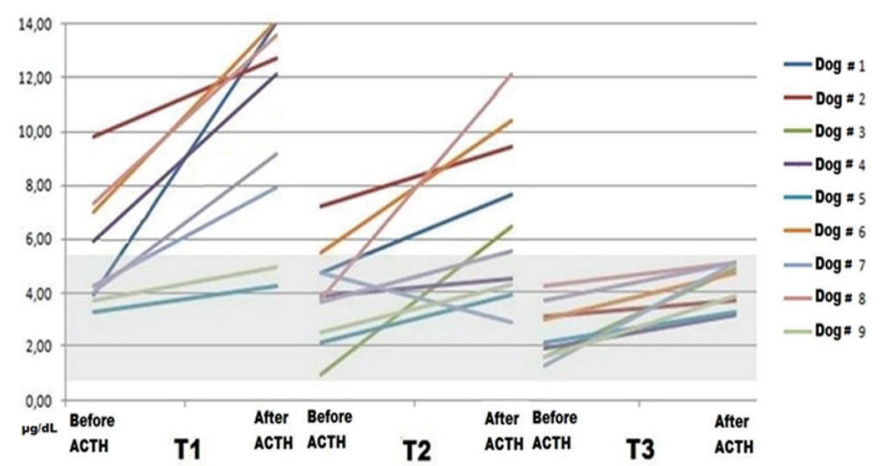

Fig.1. Adrenocorticotropic hormone stimulation test (ACTH) during follow-up (T1 to T3), before and after one hour of its administration in dogs with hyperadrenocorticism ( $\mathrm{n}=9$ dogs); the gray box indicates the expected values of serum cortisol $(\% \mathrm{~g} / \mathrm{dL})$ in dogs during treatment with trilostane.

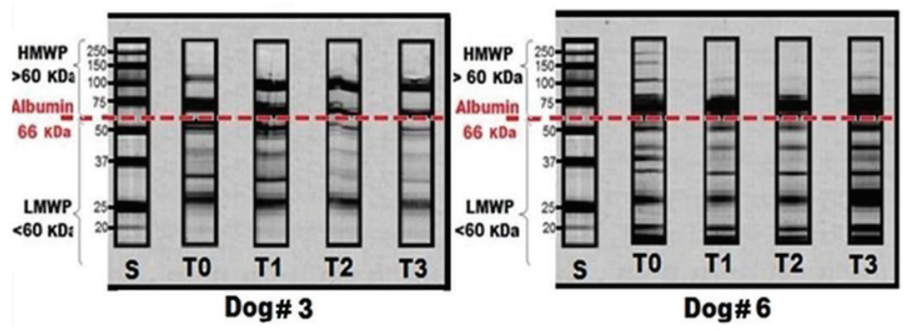

Fig.2. Electrophoresis patterns of urinary proteins by sodium dodecyl sulphate polyacrilamide gel electrophoresis (SDS - PAGE; stained with silver nitrate) in six clinically normal dogs, and in dogs with hyperadrenocorticism; Dog \#3 showing high molecular weight proteins (HMWP) and low molecular weight proteins (LMWP), UPC ranged from 0.08 to 0.13 , and Dog \# 6 showing predominance of LMWP, Dog \#6, UPC ranged from 0.14 to 0.42 . 


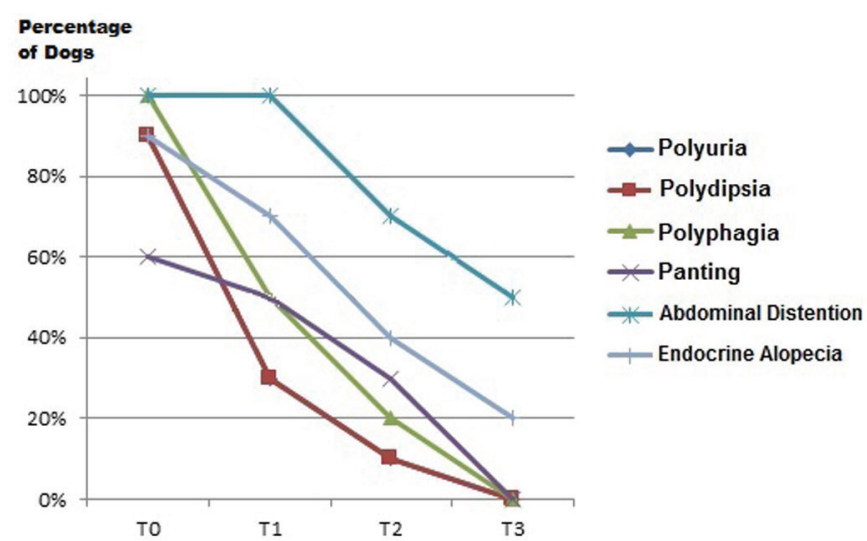

Fig.3. Clinical manifestations presented by percentage of dogs with hyperadrenocorticism before and after initiation of treatment with trilostane.

$(\mathrm{P}=0.5669)$, percentage of LMWP $(\mathrm{P}=0.5099)$, numbers of protein bands of HMWP $(\mathrm{P}=0.9456)$, and numbers of protein bands of LMWP $(\mathrm{P}=0.7307)$ (Table 1$)$.

\section{DISCUSSION AND CONCLUSION}

Hypercortisolemia is associated with the development of liver disease and steroidal or vacuolar changes occurring once the liver parenchyma, and can be detected by increased serum ALT and ALP activity. Although still not completely defined the mechanism by which glucocorticoids cause liver damage, Abdou et al. (2013) revealed that dogs with liver vacuolation secondary to excess of glucocorticoids, hepatomegaly and changes in echogenicity of the hepatic parenchyma, throughout the study the serum values of total protein and albumin remained constant, within the reference value.

Glucocorticoids regulate the differentiation, function and distribution of adipose tissue, and its effects are controversial and involve the stimulation of lipolysis in peripheral fat and lipogenesis in central fat (Arnaldi et al. 2010). The pathogenic mechanisms are multifactorial, including indirect and direct actions in lipolysis, production and degradation of free fatty acids, very low density lipoprotein synthesis and accumulation of intrahepatic fat (Arnaldi et al. 2010). Therefore, is expected that the lipid metabolism is altered in dogs with HAC, and the animals of the present study showed significantly higher serum concentrations of cholesterol and triglycerides than the control group. Glucocorticoids also induces gluconeogenesis and hepatic insulin resistance and thus dogs with hypercortisolism tend to have hyperglycemia, as shown by McCowen et al. (2001). In the present study it was also found increases in blood glucose levels when comparing the control group with T0 and this difference did not persistin long therapy (T1, T2 and T3), indicating therefore that with the decrease in serum cortisol simultaneously occurred decrease of glycaemia and thus the effects of cortisol have been minimized.

According to Lees et al. (2005), UPC between 0.5 and 1.0 in dogs without azotemia is considered questionable, and UPC $>1.0$ is pathological (Lees et al. 2005, Grauer 2011). According to the consensus of proteinuria, defined by the American College of Veterinary Internal Medicine, the per- sistence of renal proteinuria in cases of UPC above 2.0 strongly indicates glomerular disease (Lees et al. 2005). Even though the means of UPC in T0 to T3 were close to questionable values, three HAC dogs (\#4, \#7 and \#9) showed UPC above 2.0 that persisted along the follow-up period, and no abnormalities on kidneys ultrasound were found. The 6 out of 9 dogs with HAC (\#1, \#2, \#3, \#5, \#6 and \#8) were non-proteinuric (UPC $<1.0$ ), showing that any evident renal damage developed. For those non-proteinuric dogs evaluated by UPC, probably the renal damage may not developed because of the short period of follow-up, as well as because of the time course of the disease, or it could be related to therapy with trilostane that may have prevented to the progression of glomerular injury or glomerular hyperfiltration, which could indicate that the therapy may have met benefits to avoid glomerular lesions (Waters et al. 1997, Smets et al. 2012b), another evidence that the treatment decreased glomerular filtration rate values are found in the serum creatinine, which increased throughout the treatment.

However, UPC solely does not predict the segment of the nephron affected that caused the loss of proteins in the urine. The qualitative evaluation by electrophoretic pattern of urinary proteins and the identification of its molecular weight may provide additional information. In the study herein, the percentages of HMWP in dogs with HAC were lower than the control group in T0 to T3, and no significant increase or decrease in percentage of HMWP was detected along the trilostane therapy, suggesting that hypercortisolemia and/or trilostane therapy did not affect the glomerular barrier. In the other hand, with regard to the percentages of LMWP, higher percentages as well as the higher number of bands of proteins, during all the follow-up period (T0, T1, T2 and T3), were detected in comparison to the control group; some HAC dogs had $100 \%$ of LMWP. These findings may suggest the possibility of cortisol to have caused damage, mainly, to the proximal tubule cells that could interfere in reabsorption of LMWP. Thus, the qualitative assessment of proteins by means of determination of molecular weights could add more information to indicate the possible segment of the nephrons that could be associated with loss of those proteins (Zaragoza et al. 2003, Lees et al. 2005).

According to previous studies (Ortega et al. 1996, Smets et al. 2012a) in dogs with HAC, hypercortisolemia may cause not only glomerular proteinuria but also tubular proteinuria due to the injury of renal tubular cells of the proximal segment. In another study, conducted in HAC dogs by Cavalcante et al. (2013), that evaluated only in one visit the urinary albumin-to-creatinine ratio as well as the molecular weight of urinary proteins by SDS-PAGE, glomerular and tubular injuries were detected, independently of systemic arterial hypertension.

In the study conducted herein, the persistence of LMWP bands was noticed even after lowering serum cortisol as the result of trilostane therapy.

In proteinuric dogs with HAC (dogs \#4, \#7 and \#9), trilostane therapy has not changed or has not decreased the number of protein bands as well as the percentages of LMWP along the therapy, suggesting that although the 
normalization or reduction of serum cortisol was detected, as well as the improvement of clinical condition, there was no remission of the renal lesion previously detected in the proximal segment of the nephron during the period that was assessed in this study. Cortisol itself may have affected the reabsorption of proteins in the proximal convoluted tubule as higher number of bands as well as higher percentage of LMWP in non-proteinuric HAC dogs were detected throughout the course of disease and therapy, indicating that renal lesion had persisted. Smets et al. (2012a) also have found the persistence of renal proteinuria in dogs after trilostane therapy.

Another possibility that could be raised the discussion regarding to HMWP, which would characterize the presence of injury or impaired glomeruli, it refers to the albumin degradation to fragments in urine, since albumin could break upon passing through the glomeruli, resulting in LMWP and it could range from 60 to $14 \mathrm{kDa}$. (Schultze \& Jensen 1998, Zaragoza et al. 2003, Smets et al. 2012a). However, in the study herein those albumin fragments were not investigated.

In the present study was observed that hypercortisolemia in the absence of concomitant systemic hypertension caused the development of renal damage mainly at the level of the proximal segments of nephrons. Hypertension could contribute to progression of renal damage, causing glomerulosclerosis as proteinuria and glomerular disease may occur in the majority of dogs with chronic kidney disease and systemic hypertension (Schellenberg et al. 2008, Bacic et al. 2010, Reusch et al. 2010).

The qualitative longitudinal evaluation of urinary proteins suggested that hypercortisolemia may be more associated to the development of tubular than glomerular damage, and that tubular alteration persisted during the treatment period of the study. Even for the dogs that had increase in the UPC values (above 2.0), urinary LMWP predominated, showing that qualitative evaluation of proteins could provide more information regarding to the location of renal damage, and then adding more information for the better understanding of the effect of cortisol on kidneys.

Proteinuria is a frequent clinical finding in dogs with HAC. Screening for renal disease in HAC should not only include dipstick evaluation of protein in urine, it has also to be added more sensitive and specific methods to detect tubular and glomerular proteinuria as a marker of tubular and early stages of glomerular damage.

Regarding to the future of the clinical routine in veterinary medical care of patients with HAC, evaluations of proteinuria by UPC and urinary protein electrophoresis, in accordance to the results obtained in this study, those could add more information regarding to the renal damage and perhaps, in the future, it may dictate the prognosis.

The limitations of this study were that western blotting to identify the specific LMWP was not performed as well as the limited numbers of animals, and the short follow-up period.

\section{REFERENCES}

Abdou O.A., Kelany W.M., Torad F.A. \& Yehia S.G. 2013. Ultrasonographic, morphologic and biochemical alterations in experimentally induced steroid hepatopathy in dogs departmentof internal medicine and in- fectious diseases. Global Vet. 11(2):123-130. http://doi.org/10.5829/ idosi.gv.2013.11.2.74120

Alenza D.P., Arenas C., Lopez M.L. \& Melian C. 2006. Long-term efficacy of trilostane administered twice daily in dogs with pituitary-dependent hyperadrenocorticism. J. Am. Vet. Med. Assoc. 42:269-276.

Arnaldi G., Scandali V.M., Trementino L., Cardinaletti M., Appolloni G. \& Boscaro M. 2010. Pathophysiology of dyslipidemia in Cushing's syndrome. Neuroendocrinology. 92(SUPPL. 1):86-90. http://doi.org/10.1159 /000314213

Bacic A., Kogika M.M., Barbaro K.C., Iuamoto C.S., Simões D.M.N. \& Santoro M.L. 2010. Evaluation of albuminuria and its relationship with blood pressure in dogs with chronic kidney disease. Vet. Clin. Pathol. 39(2):203-209. http://doi.org/10.1111/j.1939-165X.2009.00207.

Bradford M.M. 1976. A rapid and sensitive method for the quantitation of microgram quantities of protein utilizing the principle of protein-dye binding. Anal. Biochem. 72:248-254.

Brown S., Atkins C., Bagley R., Carr A., Cowgill L., Davidson M., Labato M., Littman D., Polzin L., Ross P. \& Snyder R.S. 2007. Guidelines for the identification, evaluation, and management of systemic hypertension in dogs and cats. J. Vet. Intern. Med. 21:542-588.

Cavalcante C.Z., Kogika M.M., Bacic A., Santoro M.L., Miyashiro S.I., Sault J.P. \& Sault J.P. 2013. Avaliação da albuminúria e da eletroforese de proteínas urinárias de cães com hiperadrenocorticismo e a relação com a pressão arterial sistêmica Pesq. Vet. Bras. 33(11):1364-1370.

Cavalcante C.Z., Kogika M.M., Simões D.M.N., Oyafuso M.K., Prosser C.S., Miyashiro S.I. \& Duarte R. 2007. Microalbuminuria in dogs with hyperadrenocorticism and relationship to blood pressure. J. Vet. Intern. Med. 21:647-647.

Cho K.D., Kang J.H., Chang D., Na K.J. \& Yang M.P. 2013. Efficacy of low- and high-dose trilostane treatment in dogs $(<5 \mathrm{~kg})$ with pituitary-dependent hyperadrenocorticism. J. Vet. Intern. Med. 27(1):91-98. http://doi. org/10.1111/jvim.12007

Cook A.K. \& Cowgill L.D. 1996. Clinical and pathological features of protein-losing glomerular disease in the dog: a review of 137 cases (19851992). J. Am. Vet. Med. Assoc. 32:313-322.

Feldman E.C. 2011. Evaluation of twice-daily lower-dose trilostane treatment administered orally in dogs with naturally occurring hyperadrenocorticism. J. Vet. Intern. Med. 238(9):1321-1328.

Grauer G.F. 2011. Proteinuria: measurement and interpretation. Topics in Companion Animal Medicine. 26(3):121-127. http://doi.org/10.1053/ j.tcam.2011.04.002

Hurley K.J. \& Vaden S.L. 1998. Evaluation of urine protein content in dogs with pituitary-dependent hyperadrenocorticism. J. Am. Vet. Med. Assoc. 212(3):369-373.

Kooistra H.S. \& Galac S. 2010. Recent advances in the diagnosis of Cushing's syndrome in dogs. Vet. Clin. North Am., Small Anim. Pract. 40(2):259267. http://doi.org/10.1016/j.cvsm.2009.10.002

Lees G.E., Brown S.A., Elliott J., Grauer G.F. \& Vaden S.L. 2005. Assessment and management of proteinuria in dogs and cats: 2004 ACVIM Forum Consensus Statement (Small Animal). J. Vet. Intern. Med. 19:377-385.

McCowen K.C., Malhotra A. \& Bistrian B.R. 2001. Stress-induced hyperglycemia. Critical Care Clinics. 17(1):107-124. http://doi.org/10.1016/ S0749-0704(05)70154-8

Ortega T.M., Feldman E.C., Nelson R.W. \& Willits N.C.L. 1996. Systemic arterial blood pressure and urine protein/creatinine ratio in dogs with hyperadrenocorticism. J. Am. Vet. Med. Assoc. 209(10):1724-1729.

Peterson M.E. 2007. Diagnosis of hyperadrenocorticism in dogs. Clinical Techniques in Small Animal Practice. 22(1):2-11. http://doi.org/ 10.1053/j.ctsap.2007.02.007

Reusch C.E., Schellenberg S. \& Wenger M. 2010. Endocrine hypertension in small animals. Vet. Clin. North Am. 40(2):335-352. http://doi.org/ 10.1016/j.cvsm.2009.10.005

Schellenberg S., Mettler M., Gentilini F., Portmann R., Glaus T.M. \& Reusch C.E. 2008. The Effects of hydrocortisone on systemic arterial blood pressure and urinary protein excretion in dogs. J. Vet. Intern. Med. (22):273281. 
Schultze A. \& Jensen R. 1998. Sodium dodecyl sulfate polyacrylamide gel electrophoresis of canine urinary proteins for the analysis and differentiation of tubular and glomerular diseases. Vet. Clin. Pathol. 18(4):93-97.

Smets P.M.Y., Lefebvre H.P., Aresu L., Croubels S., Haers H., Piron K. \& Daminet S. 2012a. Renal function and morphology in aged Beagle dogs before and after hydrocortisone administration. PloS One 7(2):e31702. http:// doi.org/10.1371/journal.pone.0031702

Smets P.M.Y., Lefebvre H.P., Kooistra H.S., Meyer E., Croubels S., Maddens B.E.J. \& Daminet S. 2012b. Hypercortisolism affects glomerular and tubular function in dogs. Vet. J. 192(3):532-534. http://doi.org/10.1016/ j.tvjl.2011.05.027

Smets P.M.Y., Lefebvre H.P., Meij B.P., Croubels S., Meyer E., Van de Maele I. \& Daminet S. 2012c. Long-term follow-up of renal function in dogs after treatment for ACTH-dependent hyperadrenocorticism. J. Vet. Intern. Med. 26(3):565-74. http://doi.org/10.1111/j.1939-1676.2012.00915.x
Smets P., Meyer E., Maddens B. \& Daminet S. 2010. Cushing's syndrome, glucocorticoids and the kidney. Gen. Comp. Endocrinol. 169:1-10. http://doi.org/10.1016/j.ygcen.2010.07.004

Vaughan M.A. \& Feldman E.C. 2008. Evaluation of twice-daily, low-dose trilostane treatment administered orally in dogs with naturally occurring hyperadrenocorticism. J. Am. Vet. Med. Assoc. 232(9):1321-1328.

Waters C.B., Adams L.G., Scott-Moncrieff J.C., DeNicola D.B., Snyder P.W., White M.R. \& Gasparini M. 1997. Effects of glucocorticoid therapy on urine protein-to-creatinine ratios and renal morphology in dogs. J. Vet. Intern. Med. 11(3):172-177.

Zaragoza C., Barrera R., Centeno F., Tapia J.A. \& Mañé M.C. 2003. Characterization of renal damage in canine leptospirosis by sodium dodecyl sulphate-polyacrylamide gel electrophoresis (SDS-PAGE) and Western Blotting of the urinary proteins. J. Comp. Pathol. 129(2/3):169-178. http://doi.org/10.1016/S0021-9975(03)00029-X 